\title{
The effect of germination and metallic salts on the stability of enzymes of three high yielding varieties of maize (Zea mays L.) in respect of Bangladesh
}

\author{
${ }^{1 *}$ Rupa, A.Z., ${ }^{2}$ Sarkar, P., ${ }^{1}$ Rahman, M.M., ${ }^{1}$ Shahjadee, U.F., ${ }^{1}$ Rahman, M.M. and ${ }^{2}$ Rahman, \\ M.M. \\ ${ }^{1}$ Institute of Food Science and Technology, Bangladesh Council of Scientific and Industrial Research, \\ Dhanmondi, Dr. Kudrat-I-Khuda Road, Dhaka-1205, Bangladesh \\ ${ }^{2}$ Department of Biotechnology and Genetic Engineering, Islamic University, Kushtia-7003, Bangladesh
}

\author{
Article history: \\ Received: 16 August 2017 \\ Received in revised form: 12 \\ September 2017 \\ Accepted: 14 September 2017 \\ Available Online: 19 \\ September 2017
}

Keywords:

Germination,

Metallic salts,

Enzyme activity,

Maize

DOI:

https://doi.org/10.26656/fr.2017.2(1).172

\begin{abstract}
The study was conducted with a view to determine the effect of germination and metallic salts on nutritional quality, enzymes activity and their stability of three high yielding varieties of maize (Zea mays L.). The protein content of BHM-3, BHM-5 and BHM-6 were increased $22.37 \%, 26.48 \%$, and $20.34 \%$ respectively at 48 hours then decreased drastically from 72-96 hours of germination. Starch content was increased maximum $29.19 \%$ in BHM- 6 at 0 hours (non-germinating seeds) among the three varieties and then decreased gradually from 48-96 hours of germination. Total sugar and reducing sugar contents of BHM-3, BHM-5 and BHM- 6 seeds were maximum at 96 hours than 24-72 hours of germination while BHM-3 showed boosting increase of total sugar (336.97\%) due to 96 hours of germination. BHM-5 showed a tremendous increase of $\alpha$-amylase (189.83\%) and protease (144.44\%) activity whereas BHM-6 showed maximum invertase activity (175.27\%) at 48 hours then decreased gradually from 72-96 hours of germination. The activities of enzymes were increased in presence of metallic salts such as $\mathrm{Ca}^{2+}, \mathrm{Mg}^{2+}$, and $\mathrm{Mn}^{2+}$ while $\mathrm{Fe}^{2+}, \mathrm{Zn}^{2+}$ and $\mathrm{Cu}^{2+}$ inhibited the activities moderately.
\end{abstract}

\section{Introduction}

Of three most important food crops in the world are rice, wheat and maize (corn). These cereal seeds directly contribute more than half of all calories consumed by human beings. In terms of total pounds produced Z. mays L. is the leading cereal seed in the world (Anon, 2003). Maize is the photo-insensitive crop. It can be grown throughout the year in the subtropical climate of Bangladesh. Area and production of $Z$. mays L. in Bangladesh have been rising fast (Hussain et al., 1999). Soil texture with $30 \%$ (clay and clay-loam soil), $10 \%$ sandy soils and $\mathrm{p}^{\mathrm{H}}$ in the range of 7.5 to 8.5 supports good maize crop production (IITA, 1997). The important maize production countries in the world are South Africa, USA, China, Brazil, Argentina, Mexico, India etc. Zea mays L. provides nutrients for humans, animals and serves as basic raw materials for the production of starch, oil, protein, alcoholic beverage, food sweetener. Corn has diverse culinary applications all over the world (Kumar et al., 2013). The importance of maize in the human diet, livestock feed and as raw material for some industries had increased of the $20^{\text {th }}$ century (Badu et al., 2008). From ancient time corn has been used for various medicinal purposes (Kumar et al., 2013). A massive breakdown of reserve substances begins with the help of amylolytic, proteolytic and lipolytic enzymes during the period of germination which leads the activity of the enzyme in boosting condition. Protease, amylase and invertase are the important hydrolytic enzymes which are found in cereals, pulses and fruits etc. Germinating seeds generally exhibit high amylase and protease activities. These enzymes were studied in some cereals, legume seeds (Koshiba and Minamikawa, 1983; Morohasi, 1986; Rahman et al., 2006). It was observed that protease activities present in dry seeds were enhanced during germination (Harvey and Oaks, 1974). Availability of literature, the present research works were planned to observe the effect of germination and metallic salts on nutritional quality, enzymes activity and their stability of three different varieties of maize. 


\section{Materials and methods}

\subsection{Zea mays L. seed sample collection}

Three Zea mays L. seed samples were collected from Bangladesh Agricultural Research Institute (BARI) namely BHM-3, BHM-5 and BHM-6. All the apparatus were provided by the Food Enzymology section of IFST of BCSIR, Dhaka-1205. Chemicals and solvents used in the study were of analytical reagents grade.

\subsection{Germination test}

For germination test, $0.5 \%$ aqueous solution of calcium hypochlorite was used for surface sterilization of Zea mays L. seeds. Seeds were surface sterilized to avoid microbial infection by soaking the seeds with $0.5 \%$ calcium hypochlorite for two minutes followed by washing 7 to 8 times with distilled water to remove any trace of hypochlorite. Then the seeds were kept on Whatman No.1 $(9 \mathrm{~cm})$ soaked filter paper in sterilized petri dishes. Distilled water was applied to the experimental seeds at an interval an of 24 hours, 48 hours, 72 hours and 96 hours germination.

\subsection{Determination of proximate analysis}

Among proximate analysis, protein content was determined using Macro-Kjeldahl AOAC method (2000). Other proximate analysis includes fat, carbohydrate, ash, fibre and moisture contents of raw and germinated maize seeds evaluated (Ranganna, 1991). Soxhlet apparatus was used for determination of fat by hexane and petroleum benzene $\left(40^{\circ} \mathrm{C}-60^{\circ} \mathrm{C}\right)$ extraction for 6 hours. Ash content was calculated by 6 hours of burning in muffle furnace at $600^{\circ} \mathrm{C}$. Moisture meter was used for determination of moisture content at $105 \pm 5^{\circ} \mathrm{C}$ temperature. Fiber content was measured by using $0.255 \mathrm{~N} \mathrm{H}_{2} \mathrm{SO}_{4}$ and $0.313 \mathrm{~N} \mathrm{NaOH}$ solution. Starch, reducing sugar and total sugar contents of different seeds were determined by following the method of Ranganna (1991). The mineral content (calcium, phosphorus, and iron) were determined by the method of Anon. (1976).

\subsection{Assay of enzyme activity}

\subsubsection{Preparation of crude enzymes extract}

The seeds ( $2 \mathrm{gm})$ were grinded in a mortar with cold $0.1 \mathrm{M}$ phosphate buffer of respective $\mathrm{pH}$, for amylase (6.7) and for protease citrate buffer (5.5) and finally crushed into paste using a homogenizer. The temperature was maintained at $4^{\circ} \mathrm{C}$ by putting ice in the outer chamber of the homogenizer. The suspension was then filtered through few layers of cheesecloth in the cold room. The filtrate was collected and clarified further by centrifugation in a refrigerated centrifuge at 10,000 r.p.m. for 20 minutes at $4^{\circ} \mathrm{C}$ and used as crude enzyme extract. Amylase activity was assayed following the method as described by Jayaraman (1981). Protease and invertase activity were assayed following the modified method as described by Mahadevan and Sridhar (1982).

\subsection{Effect of metallic salts}

Metallic salts at different concentrations were added to $5.0 \mathrm{ml}$ of amylase, protease and invertase enzymes extract solutions from BHM-5 variety and incubated for 10 minutes at $20^{\circ} \mathrm{C}$. The mixtures were again incubated with the substrate for 15 minutes at $37^{\circ} \mathrm{C}$ and the enzyme activities were assayed.

\section{Results and discussion}

Table 1. Proximate composition of different varieties of Zea mays L. seed

\begin{tabular}{|c|c|c|c|}
\hline \multirow{2}{*}{ Parameters } & \multicolumn{3}{|c|}{ Name of Zea mays L. varieties } \\
\hline & BHM-3 & BHM-5 & BHM-6 \\
\hline Moisture (\%) & $9.36 \pm 0.02$ & $10.48 \pm 0.03$ & $9.62 \pm 0.02$ \\
\hline Ash (\%) & $1.36 \pm 0.10$ & $1.12 \pm 0.15$ & $1.43 \pm 0.09$ \\
\hline Protein $(\%)$ & $10.95 \pm 0.21$ & $10.50 \pm 0.33$ & $11.65 \pm 0.28$ \\
\hline Fat $(\%)$ & $5.380 \pm 0.42$ & $5.08 \pm 0.39$ & $5.21 \pm 0.41$ \\
\hline $\begin{array}{l}\text { Crude Fibre } \\
(\%)\end{array}$ & $2.09 \pm 0.02$ & $1.81 \pm 0.01$ & $1.82 \pm 0.02$ \\
\hline $\begin{array}{l}\text { Carbohydrate } \\
(\%)\end{array}$ & $72.95 \pm 0.32$ & $72.82 \pm 0.29$ & $72.10 \pm 0.36$ \\
\hline $\begin{array}{l}\text { Energy (kcal } \\
\text { per } 100 \mathrm{gm})\end{array}$ & $394.02 \pm 0.42$ & $388.48 \pm 0.38$ & $391.51 \pm 0.39$ \\
\hline Starch $(\%)$ & $65.72 \pm 0.09$ & $64.88 \pm 0.18$ & $65.78 \pm 0.21$ \\
\hline $\begin{array}{l}\text { Total Sugar } \\
\text { (\%) }\end{array}$ & $3.30 \pm 0.10$ & $3.38 \pm 0.08$ & $3.29 \pm 0.11$ \\
\hline $\begin{array}{l}\text { Reducing } \\
\text { Sugar (\%) }\end{array}$ & $1.10 \pm 0.04$ & $1.04 \pm 0.04$ & $1.08 \pm 0.06$ \\
\hline $\begin{array}{l}\text { Calcium } \\
(\mathrm{mg} / 100 \mathrm{gm})\end{array}$ & $48.30 \pm 0.22$ & $44.70 \pm 0.30$ & $50.60 \pm 0.23$ \\
\hline $\begin{array}{l}\text { Phosphorus } \\
\text { (mg/100gm) }\end{array}$ & $252.0 \pm 0.36$ & $244.0 \pm 0.41$ & $264.0 \pm 0.39$ \\
\hline $\begin{array}{l}\text { Iron } \\
(\mathrm{mg} / 100 \mathrm{gm})\end{array}$ & $2.54 \pm 0.03$ & $2.14 \pm 0.02$ & $2.60 \pm 0.03$ \\
\hline
\end{tabular}

The values are mean $\pm \mathrm{SD}$ of determinations made in triplicates.

\subsection{Proximate analysis}

The results of the proximate analysis of three different Zea mays L. are shown in Table 1.The moisture content of BHM-3, BHM-5, BHM-6 was found 9.36\%, $10.48 \%, 9.62 \%$ respectively (Table 1 ).Cereal seeds are usually harvested at $20-25 \%$ moisture content while $14 \%$ or less is considered safe for storing grains, $12 \%$ or less for storing seeds (Stefania et al., 2005). The ash content 
of Zea mays L. seed BHM-3, BHM-5, BHM-6 was $1.36 \%, 1.12 \%$ and $1.43 \%$ respectively (Table 1 ) which is similar to Peplinski (1889). Maziya-Dixon et al. (2000) found results in the range of $1.4-3.3 \%$, which is slightly higher than the values determined in the present study. The second largest chemical component of the Zea mays L. seed is protein. The protein content of Zea mays L. BHM-3, BHM-5, BHM-6 were found 10.95\%, 10.50\% and $11.65 \%$ respectively (Table 1 ) which were similar to the value $10.67-11.27 \%$ mentioned by Ijabadeniyi and Adebolu (2005) of three Zea mays L. varieties grown in Nigeria. The fat content of Zea mays L. BHM-3, BHM5, BHM-6 varieties were 5.38\%, 5.08\%, and 5.21\% respectively (Table 1). Ijabadeniyi and Adebolu (2005) determined the percentage of fat content of three Zea mays L. varieties grown in Nigeria in the range of 4.77$5.00 \%$ which is in close consistency with the present study. The fibre content of BHM-3 variety was found to be the highest (2.09\%) followed by BHM-6 (1.82\%) and the lowest amount was found in BHM-5 (1.81\%). Ullah et al. (2010) mentioned the crude fibre content of different Zea mays L. varieties were in the range of 0.80 $2.32 \%$ which is in close agreement with the present study. Carbohydrate is the major chemical component of the Zea mays L. seed. The carbohydrate content of BHM -3 , BHM-5 and BHM-6 were found $72.95 \%, 72.82 \%$ and $72.10 \%$ respectively (Table 1 ). These results are also in agreement with other scientific works of Ullah et al. (2010) who mentioned the carbohydrate content of different Zea mays L. varieties were in the range of $69.66 \%-74.55 \%$. The energy content of BHM-3 variety was found to be the highest (394.02\%) followed by BHM-6 (391.51\%) and BHM-5 (388.48\%) which is also similar to Ullah et al. (2010) and Kouakou et al. (2008). In another study Ejigue et al. (2005) found the energy value $447 \mathrm{kcal} / 100 \mathrm{~g}$ for yellow Zea mays $\mathrm{L}$. which is higher than the values determined in this study. The results of the present studies showed that Zea mays L. varieties are a rich source of energy as compared to other crops. The starch content of BHM-6 variety was found to be the highest $(65.78 \%)$ followed by BHM-3 (65.72\%) and BHM-5 (64.88\%) presented in Table 1, supported by Guria (2006). According to Rahman et al. (2011) the total and reducing sugar contents were varied from 3.29\%-3.38\% and 1.04\%-1.10\% (Table 1). Mejía (2003) reported that calcium and phosphorus were found highest in BHM-6 (50.60 mg/100gm and $264.0 \mathrm{mg} / 100 \mathrm{gm}$ ) followed by BHM-3 (48.30 mg/100gm and 252.0 $\mathrm{mg} / 100 \mathrm{gm})$ and BHM-5 (44.70 $\mathrm{mg} / 100 \mathrm{gm}$ and 244.0 $\mathrm{mg} / 100 \mathrm{gm})$ presented in Table 1 . The iron content of BHM-6 variety was found highest $(2.60 \mathrm{mg} / 100 \mathrm{gm})$ followed by BHM-3 (2.54 mg/100gm) and BHM-5 (2.14 $\mathrm{mg} / 100 \mathrm{gm}$ ) which were similar to Guria (2006). This slight difference might be as a result of fertilizer application, the rate of parboiling and the amounts of soil nutrients which affect the mineral contents.

\subsection{Determination of protein content during germination}

It was observed that due to germination, the protein content of BHM-3, BHM-5 and BHM- 6 were increased maximum $22.37 \%, 13.28 \%$, and $20.34 \%$ respectively at 48 hours of germination then decreased drastically after 72 and 96 hours of germination. Maximum decreases of protein were $20.73 \%, 24.29 \%$ and $19.66 \%$ at 96 hours of germination (Table 2). Several studies on the effect of germination on cereals and legumes found that germination can increase protein content and dietary fibre; reduce tannin and phytic acid content and increase mineral bioavailability (Rao and Prabhavathi, 1982; Hussein and Ghanem, 1999). Hahm et al. (2008) suggested that protein content of cereals and legumes deceased at a certain period because amino acids are oxidized to carbon dioxide and water to generate energy for germination.

Table 2. Changes of protein content of Zea mays L. seed during different germinating period

\begin{tabular}{lccccc}
\hline \multirow{2}{*}{ Variety } & \multicolumn{5}{c}{ Duration of germination (Protein \%) } \\
\cline { 2 - 6 } & $0 \mathrm{hrs}$ & $24 \mathrm{hrs}$ & $48 \mathrm{hrs}$ & $72 \mathrm{hrs}$ & $96 \mathrm{hrs}$ \\
\hline \multirow{2}{*}{ BHM-3 } & $10.95 \pm$ & $12.76 \pm$ & $13.40 \pm$ & $11.48 \pm$ & $8.68 \pm$ \\
& 0.21 & 0.29 & 0.31 & 0.33 & 0.25 \\
BHM-5 & $10.50 \pm$ & $12.25 \pm$ & $13.28 \pm$ & $11.22 \pm$ & $7.95 \pm$ \\
& 0.33 & 0.40 & 0.42 & 0.38 & 0.29 \\
BHM-6 & $11.65 \pm$ & $13.51 \pm$ & $14.02 \pm$ & $12.06 \pm$ & $9.36 \pm$ \\
& 0.29 & 0.26 & 0.32 & 0.28 & 0.31 \\
\hline
\end{tabular}

The values are mean \pm SD of determinations made in triplicates.

\subsection{Enzyme activity during germination}

Enzyme activities of maize seed during the different germinating period were summarized in Table 3. During the different germination period, the highest $\alpha$-amylase activity was found at 48 hours in BHM-6 (3.64 unit/gm) followed by BHM-3 (3.48 unit/gm) and BHM-5 (3.42 unit/gm). The present findings indicated that amylase activity increased in BHM-5 (189.83\%) and BHM-6 (188.89\%) and BHM-3 (185.25\%) and the invertase activity increased $175.27 \%, 174.42 \%$ and $170.0 \%$ respectively at 48 hours of germination and there after decreased drastically. During the different germination period, the highest invertase activity was found at 48 hours in BHM-3, BHM-5 and BHM-6 (2.36 unit/gm, $2.43 \mathrm{unit} / \mathrm{gm}$ and $2.56 \mathrm{unit} / \mathrm{gm})$. The higher protease activity was found at 48 hours in BHM-3, BHM-5 and 
Table 3. $\alpha$-amylase, invertase and protease activities of Zea mays L. seed during the period of germination

\begin{tabular}{|c|c|c|c|c|c|c|}
\hline \multirow{2}{*}{ Variety } & \multirow{2}{*}{$\begin{array}{l}\text { Relative } \\
\text { activity }\end{array}$} & \multicolumn{5}{|c|}{ Duration of germination } \\
\hline & & $0 \mathrm{hrs}$ & $24 \mathrm{hrs}$ & $48 \mathrm{hrs}$ & $72 \mathrm{hrs}$ & $96 \mathrm{hrs}$ \\
\hline BHM-3 & \multirow{3}{*}{$\begin{array}{l}\alpha \text {-amylase } \\
\text { (unit/gm) }\end{array}$} & $1.22 \pm 0.01$ & $2.74 \pm 0.03$ & $3.48 \pm 0.11$ & $2.80 \pm 0.21$ & $1.95 \pm 0.13$ \\
\hline BHM-5 & & $1.18 \pm 0.05$ & $2.70 \pm 0.02$ & $3.42 \pm 0.03$ & $2.76 \pm 0.04$ & $1.78 \pm 0.21$ \\
\hline BHM-6 & & $1.26 \pm 0.02$ & $2.78 \pm 0.10$ & $3.64 \pm 0.13$ & $2.88 \pm 0.09$ & $1.98 \pm 0.11$ \\
\hline BHM-3 & \multirow{3}{*}{$\begin{array}{l}\text { Invertase } \\
\text { (unit/gm) }\end{array}$} & $0.86 \pm 0.05$ & $1.56 \pm 0.14$ & $2.36 \pm 0.13$ & $1.72 \pm 0.09$ & $1.08 \pm 0.17$ \\
\hline BHM-5 & & $0.90 \pm 0.02$ & $1.62 \pm 0.22$ & $2.43 \pm 0.19$ & $1.80 \pm 0.08$ & $1.16 \pm 0.14$ \\
\hline BHM-6 & & $0.93 \pm 0.10$ & $1.65 \pm 0.23$ & $2.56 \pm 0.32$ & $1.92 \pm 0.24$ & $1.24 \pm 0.09$ \\
\hline BHM-3 & \multirow{3}{*}{$\begin{array}{l}\text { Protease } \\
\text { (unit/gm) }\end{array}$} & $1.92 \pm 0.33$ & $2.81 \pm 0.25$ & $4.48 \pm 0.22$ & $3.72 \pm 0.42$ & $2.46 \pm 0.32$ \\
\hline ВHМ-5 & & $1.80 \pm 0.07$ & $2.64 \pm 0.31$ & $4.40 \pm 0.36$ & $2.62 \pm 0.17$ & $2.18 \pm 0.43$ \\
\hline ВНМ-6 & & $2.06 \pm 0.31$ & $2.90 \pm 0.11$ & $4.52 \pm 0.44$ & $3.16 \pm 0.32$ & $2.76 \pm 0.44$ \\
\hline
\end{tabular}

The values are mean $\pm \mathrm{SD}$ of determinations made in triplicates.

Table 4. Changes of starch, total sugar and reducing sugar content of Zea mays L. seed during different germinating period

\begin{tabular}{ccccccc}
\hline \multirow{2}{*}{ Parameters } & Variety & \multicolumn{5}{c}{ Duration of germination } \\
\cline { 3 - 7 } & & $0 \mathrm{hrs}$ & $24 \mathrm{hrs}$ & $48 \mathrm{hrs}$ & $72 \mathrm{hrs}$ & $96 \mathrm{hrs}$ \\
\hline \multirow{2}{*}{ Starch (\%) } & BHM-3 & $65.72 \pm 0.35$ & $52.71 \pm 0.36$ & $38.29 \pm 0.41$ & $36.80 \pm 0.12$ & $31.03 \pm 0.19$ \\
& BHM-5 & $64.88 \pm 0.24$ & $51.74 \pm 0.31$ & $39.79 \pm 0.45$ & $35.80 \pm 0.36$ & $29.26 \pm 0.43$ \\
Total sugar & BHM-3 & $3.30 \pm 0.25$ & $7.86 \pm 0.39$ & $10.13 \pm 0.41$ & $12.15 \pm 0.34$ & $14.42 \pm 0.42$ \\
(\%) & BHM-5 & $3.38 \pm 0.03$ & $7.86 \pm 0.36$ & $10.13 \pm 0.28$ & $11.92 \pm 0.41$ & $14.56 \pm 0.37$ \\
& BHM-6 & $3.29 \pm 0.05$ & $7.63 \pm 0.40$ & $10.13 \pm 0.31$ & $11.86 \pm 0.39$ & $14.59 \pm 0.40$ \\
Reducing sugar & BHM-3 & $1.10 \pm 0.03$ & $1.24 \pm 0.06$ & $1.53 \pm 0.11$ & $1.96 \pm 0.09$ & $2.35 \pm 0.10$ \\
$(\%)$ & BHM-5 & $1.04 \pm 0.06$ & $1.18 \pm 0.07$ & $1.43 \pm 0.09$ & $1.95 \pm 0.13$ & $2.24 \pm 0.20$ \\
& BHM-6 & $1.08 \pm 0.08$ & $1.22 \pm 0.06$ & $1.48 \pm 0.10$ & $2.06 \pm 0.17$ & $2.32 \pm 0.21$ \\
\hline
\end{tabular}

The values are mean \pm SD of determinations made in triplicates.

BHM-6 (4.48 unit/gm, 4.40 unit/ gm and 4.52 unit/gm). Enzyme activities were decreased drastically from 72-96 hours due to germination. Results were supported by Koshiba and Minamikawa (1983). In cereal seeds, germination increase oligosaccharides and amino acids concentration as observed in barley (Rimsten et al., 2003), wheat (Yang et al., 2001) and rice (Manna et al., 1995). It was established that a number of dry matters reduced in germinated wheat and the content of mineral substances, protein and activity of fermented $\alpha$-and $\beta$ amylases, cellulases, proteases, and maltase were greater than in non-germinated wheat, observed by Kraujutiene et al. (2010).

\subsection{Determination of starch, total sugar and reducing sugar during germination}

Table 4 showed that starch content of three high yielding varieties was increased remarkably $22.19 \%$, $20.25 \%$ and $19.79 \%$ due to 24 hours of germination then decreased drastically from 48-96 hours of germination.
BHM-3, BHM-5, and BHM-6 showed a higher amount of starch $52.71 \%, 51.74 \%$ and $51.18 \%$ at 24 hours of germination and maximum decrease were $52.78 \%$, $54.90 \%$ and $47.07 \%$ respectively at 96 hours of germination. Results were similar to the findings of Kashem et al. (1995). Stored starch plays an important role in the development of embryo during germination of seeds. The increase in metabolic activity in germinating seeds is due to the induction of some of the hydrolytic enzymes. It was observed that due to germination total sugar content of BHM-3 increased remarkably 336.97\% at 96 hours of germination, whereas it was decreased drastically from 24-72 hours of germination (Table 4). Followed by Ali (1992) and Jood et al. 1998 it was observed that due to germination reducing sugar content increased significantly at 96 hours of germination whereas it was decreased drastically from 24-72 hours of germination. During germination, there was a decrease in storage carbohydrates and an increase in total soluble sugar. This might be due to the requirement of energy by 
growing utilization and rapid translocation of amino acids to the growing axes.

\subsection{Metallic salts}

Table 5. Effect of various metallic salts on the activities of $\alpha$ amylase, invertase and protease

\begin{tabular}{ccccc}
\hline \multirow{2}{*}{$\begin{array}{c}\text { Test } \\
\text { Salts }\end{array}$} & $\begin{array}{c}\text { Concentr } \\
\text { ation } \\
\text { (Molar) }\end{array}$ & \multicolumn{3}{c}{ Relative activities (\%) } \\
\cline { 3 - 5 } None & - & 100.00 & 100.00 & 100.00 \\
& 0.001 & 104.72 & 103.54 & 105.00 \\
$\mathrm{MgCl}_{2}$ & 0.002 & 107.34 & 106.36 & 108.12 \\
& 0.001 & 84.24 & 86.80 & 92.25 \\
$\mathrm{ZnCl}_{2}$ & 0.002 & 72.20 & 74.32 & 88.52 \\
& 0.001 & 85.70 & 64.62 & 70.84 \\
$\mathrm{CuCl}_{2}$ & 0.002 & 75.35 & 50.28 & 52.64 \\
& 0.001 & 116.74 & 110.26 & 112.46 \\
$\mathrm{MnCl}_{2}$ & 0.002 & 126.62 & 118.42 & 120.66 \\
& 0.001 & 100.00 & 99.32 & 99.68 \\
$\mathrm{NaCl}_{2}$ & 0.002 & 99.74 & 97.46 & 98.78 \\
& 0.001 & 100.00 & 100.00 & 100.00 \\
$\mathrm{KCl}_{2}$ & 0.002 & 100.00 & 100.00 & 100.00 \\
& 0.001 & 72.16 & 64.46 & 66.28 \\
$\mathrm{FeCl}_{2}$ & 0.002 & 58.46 & 50.74 & 52.24 \\
\hline \multirow{2}{*}{} & & & &
\end{tabular}

Table 5 represents the effect of various metallic salts on the activities of three enzymes. The activities of enzymes were increased remarkably in the presence of $\mathrm{Mn}^{2+}$ salts while that was increased slightly in the presence of $\mathrm{Mg}^{2+}$ salts. Other metallic salts such as $\mathrm{K}^{2+}$ and $\mathrm{Na}^{2+}$ produce little or no inhibitory effects on the activities of the enzymes but the activities of all the enzymes reduce significantly in the presence of $\mathrm{Zn}^{2+}, \mathrm{Cu}^{2+}$ and $\mathrm{Fe}^{2+}$. The activities of the enzymes increased significantly in the presence of divalent cations $\mathrm{Ca}^{2+}$ and $\mathrm{Mn}^{2+}$ suggesting the involvement of these divalent ions in maintaining the active conformation of the enzymes which are partially in accordance with the results of Akand et al. 2003.

\section{Conclusion}

The test results represent that among three high yielding varieties of Zea mays L., BHM-3 was rich in energy and BHM-6 was higher in protein, starch, and mineral. This study could be concluded that germination is a more effective process for improving nutritional value, enzyme activities and functional qualities of $\mathrm{Zea}$ mays $L$. seeds. Protein and enzyme activities were increased tremendously during 48 hours of germination. On the other hand, starch content decreased but reducing sugar and total sugar content were increased gradually from 0-96 hours of germination. The activities of enzymes were increased in presence of metallic salts such as $\mathrm{Ca}^{2+}, \mathrm{Mg}^{2+}$, and $\mathrm{Mn}^{2+}$ while $\mathrm{Fe}^{2+}, \mathrm{Zn}^{2+}$ and $\mathrm{Cu}^{2+}$ inhibited the activities moderately.

\section{Acknowledgements}

Author thanks, BCSIR, Dhaka-1205, for all necessary cooperation regarding this research purposes.

\section{References}

Association of Analytical Chemists (AOAC). (2000). Official Methods of Analylsis. $17^{\text {th }}$ ed. Washington, D.C.: Association of Analytical Chemists, Inc.

Akand, A.H. (2003). Effect of physic-chemical agents on the activity of invertase purified from mango-pulp of himsagar variety. Journal of Applied Science and Technology, 3(2), 11-16.

Ali, A.H. (1992). Growth and protein content of Cassia senna L. Seedlings. Journal of King Saud University of Science, 4(1), 5-13.

Anon. (2003). Diet, nutrition and the prevention of chronic diseases. In WHO Technical Report Series, Geneva, No. 916, 1-150.

Anon. (1976). Manual of Laboratory Techniques. Analysis of foodstuffs, p. 3-5. Hyderabad, India: National Institute of Nutrition, Indian Council of Medical Research.

Badu, A.B., Fontem, L.A., Fakoredev, M.A.B., Menkir, A., Chabi, T., Abdulai, C., Jacob, S. and Agbaje, S. (2008). Performance of early maize cultivars derived from recurrent selection for grain yield and striga resistance. Crop Science, 48, 99-112.

Ejigue, J., Savoie, L., Marin, J. and Desrosier, T. (2005). Beneficial changes and drawbacks of traditional fermentation process on chemical composition and antinutritional factors of yellow maize (Zea mays L.). Journal of Biology and Science, 5, 590-596.

Guria, P. (2006). Physico-chemical properties, nutritional quality, and value added to quality protein maize (Zea mays L.). Dharwad: University of Agriculture and Science, MSc thesis.

Hahm, T., Park, S. and Lo, Y.M. (2008). Effects of germination on chemical composition and functional properties of sesame (Sesamum indicum L.) seeds. Journal of Biotechnology, 100(4), 1643-1647.

Harvey, B.M.R. and Oaks, A. (1974). The hydrolysis of endosperm protein in Zea mays L. Plant Physiology, 


\section{$53,453-457$.}

Hussein, L. and Ghanem, K.Z. (1999). Calcium bioavailability from selected Egyptian foods with emphasis on the impact of germination and fermentation. International Journal of Food Science and Nutrition, 50(5), 351-356.

Ijabadeniyi, A.O. and Adebolu, T.T. (2005). The effect of processing methods on the nutritional properties of ogi produced from three maize varieties. Journal of Food, Agriculture and Environment, 3, 108-109.

International Institute of Tropical Agriculture (IITA). (April 1997). Phenomenal increase in maize production in West and Central Africa. Retrieved on January 1, 2017 from website: www.cgiar.org/webarchives/www-worldbank-org-html-cgiar-newsletterApril 97-8 maize-html.

Jayaraman, J. (1981). Laboratory Manual in Biochemistry. New Delhi, India: Wiley Eastern Ltd.

Kashem, A.M., Sultana, N., Samanta, C.S. and Kamal, A.M.A. (1995). Starch, sugar, amylase and invertase activity in the germination seeds of modern wheat varieties. Journal of Natural Science Council, 23(2), 55-60.

Koshiba, T.O. and Minamikawa, T. (1983). In vivo synthesis and turnover of $\alpha$-amylase in attached and detached cotyledons of Vigna mungo L. seeds. Plant Physiology, 71(1), 173-176.

Kouakou, B.G., Albarini, O.A., Louuise, D.N., Theodore, K., Youssouf. and Dago, G. (2008). Assessment of some chemical and nutritional properties of maize, rice and millet grains and their weaning mushes. Pakistan Journal of Nutrition, 7, 721-725.

Kraujutiene, I., Steponavicius, D., Matusevicius, P. and Steponaviciene, A. (2010). Comparative evaluation of qualitative values in germinated and ungerminated wheat grain grown in different technologies. Annals of Food Science and Technology, 11, 6-12.

Kumar, P.D., Panda, A.K.,Behera, R.K., Jha. S., Mishra, M.R., Mishara, A. and Chowdhury, S. (2013). Ethno medicinal and potential of SIDA ACUTA BURM. F. International Research Journal of Pharmacy, 4(1), 89-92.

Mahadevan, A. and Sridhar, R. (1982). Methods of physiological plant pathology. $2^{\text {nd }}$ ed. Madras, India: Sivakami publications.

Manna, K.M., Naing, K.M. and Pe, H. (1995). Amylase activity of some roots and sprouted cereals and beans. Food and Nutrition Bulletin, 16(2), 1- 4.
Maziya, D.B.B., Kling, J.G. and Okoruwa, A.E. (2000). Physical, chemical and water absorption characteristics of tropical maize hybrids Africa. Crop Science, 8, 419-428.

Mejía, D. (2003). Maize: post-harvest operation. Report of the Food and Agriculture Organization of the United Nations (FAO), AGST, p. 39-41. Rome: FAO

Peplinski, A.J., Paulsen, M.R., Anderson, R.A. and Kwolek, W.F. (1989). Physical, chemical and drymilling characteristics of corn hybrids from various genotypes. Journal of Cereal Chemistry, 66, 117120.

Rahman, M.M. and Banu, L.A. (2006). Changes in the protein and minerals content during germination of mung bean varieties. Bangladesh Journal of Agriculture, 31 (1 and 2), 101-103.

Rahman, Z.M., Azad, K.A., Rahman, M.M., Banu, A.L., Rahman, M.M. and Shahjadee, F.U. (2011). Biochemical analysis of different varieties of blackgram (Vigna mungo L.). Journal of Applied Science and Technology, 8(1), 96-97.

Ranganna, S. (1991). Handbook of analysis and quality control for fruit and vegetable products. $2^{\text {nd }} \mathrm{ed}$. Delhi, India: Tata McGraw Hill publication.

Rao, B.S.N. and Prabhavathi, T. (1982). Tannin content of foods commonly consumed in India and its influence on ionisable iron. Journal of the Science of Food and Agriculture, 33(1), 89-96.

Rimsten, L., Haraldsson, A.K., Andersson, R., Alminger, M., Sandberg, A.S. and Aman, P. (2003). Effects of malting on beta-glucanase and phytase activity in barley grain. Journal of the Science of Food and Agriculture, 82(8), 904-912.

Stefania, G. and Macpherson, H.G. (2005). Food Barley. In El-Haramein, F.J. (Eds). Proceedings of the International Workshop on Food Barley Improvement, p. 141-145. Aleppo: Syria.

Ullah, I., Ali, M. and Farooqi, A. (2010). Chemical and nutrition properties of some maize (Zea mays L.) varieties grown in NWFP. Pakistan Journal of Nutrition, 9(11), 1114-1115.

Yang, F., Basu, T.K. and Ooraikul, B. (2001). Studies on germination conditions and antioxidant contents of wheat grain. International Journal of Food Science and Nutrition, 52(4), 319-330. 